\title{
Research Article \\ Effects of Uptake of Hydroxyapatite Nanoparticles into Hepatoma Cells on Cell Adhesion and Proliferation
}

\author{
Meizhen Yin, ${ }^{1}$ Yixia Yin, ${ }^{2}$ Yingchao Han, ${ }^{2}$ Honglian Dai, ${ }^{2}$ and Shipu $\mathrm{Li}^{2}$ \\ ${ }^{1}$ School of Medicine, Hubei Polytechnic University, Hubei, Huangshi 435003, China \\ ${ }^{2}$ State Key Laboratory of Advanced Technology for Materials Synthesis and Processing and Biomedical Materials \\ and Engineering Center, Wuhan University of Technology, Wuhan 430070, China
}

Correspondence should be addressed to Yixia Yin; yinyixia@whut.edu.cn

Received 16 January 2014; Revised 20 February 2014; Accepted 20 February 2014; Published 20 March 2014

Academic Editor: Zhongkui Hong

Copyright (C) 2014 Meizhen Yin et al. This is an open access article distributed under the Creative Commons Attribution License, which permits unrestricted use, distribution, and reproduction in any medium, provided the original work is properly cited.

\begin{abstract}
Hydroxyapatite nanoparticles (nano-HAPs) were prepared by homogeneous precipitation, and size distribution and morphology of these nanoparticles were determined by laser particle analysis and transmission electron microscopy, respectively. NanoHAPs were uniformly distributed, with rod-like shapes sizes ranging from 44.6 to $86.8 \mathrm{~nm}$. Attached overnight, suspended, and proliferating Bel-7402 cells were repeatedly incubated with nano-HAPs. Inverted microscopy, transmission electron microscopy, and fluorescence microscopy were used to observe the cell adhesion and growth, the culture medium containing nano-HAPs, the cell ultrastructure, and intracellular $\mathrm{Ca}^{2+}$ labeled with a fluo-3 calcium fluorescent probe. The results showed that nano-HAPs inhibited proliferation of Bel-7402 cells and, caused an obvious increase in the concentration of intracellular $\mathrm{Ca}^{2+}$, along with significant changes in the cell ultrastructure. Moreover, nano-HAPs led suspended cells and proliferating cells after trypsinized that did not attach to the bottom of the culture bottle died. Nano-HAPs continuously entered these cells. Attached, suspended, and proliferating cells endocytosed nano-HAPs, and nanoparticle-filled vesicles were in the cytoplasm. Therefore, hepatoma cellular uptake of nano-HAPs through endocytosis was very active and occurred continuously. Nano-HAPs affected proliferation and adhesion of hepatoma cells probably because uptake of nano-HAPs blocked integrin-mediated cell adhesion, which may have potential significance in inhibiting metastatic cancer cells to their target organ.
\end{abstract}

\section{Introduction}

Nanoparticles with diameters of $1-100 \mathrm{~nm}$ have been used in numerous physical, biomedical, and pharmaceutical fields because of their unique physical, chemical, and biological properties [1]. With advancements in nanotechnology, hydroxyapatite (HAP), the primary inorganic component of bone and teeth, has been developed for biomedical use, considering its extraordinary properties. Nano-HAP may be an ideal biomaterial because of its good biocompatibility and bone integrating ability [2]. nHAP-Zn nanoparticles have potential applications in bone tissue engineering because of their antimicrobial properties [3]. Nano-HAP-Sr powders possess osteoconductive and osteoinductive properties and have potential in repairing bone defects caused by osteoporotic fractures [4]. Particularly, more efforts have been made to explore the potential of nano-HAPs as anticancer drug. Nano-HAPs are believed to be able to restrain growth of human cancer MGc80-3 cells, osteosarcoma Os-732 cells, esophageal Ec-109 cells, and 10 other tumor cells in vitro. Moreover, nano-HAPs have an inhibitory action and induce apoptosis in human glioma cells in vitro and in vivo; further, they significantly reduce the adverse reaction related to the chemotherapeutic drug 1,3-bis(2-chloroethyl)-1-nitrosourea in a drug combination [5]. More importantly, some studies have indicated that nano-HAPs are more cytotoxic to tumor cells and less harmful to normal cells. Qing et al. [6] reported that nano-HAPs support proliferation of normal bone cells (osteoblasts) while causing apoptosis in osteosarcoma cells (MG63). In addition, Tang et al. [7] reported that nano-HAPs significantly inhibit cell proliferation and induce apoptosis in cancer cells in an order of MGC80-3 > HepG2 > HeLa but have no impact on normal hepatic cells (L-02). Some more recent studies indicate that nano-HAPs have the potential to 
be used as drug and gene carriers because of their affinity for various drugs and DNA as well as their fine release property [8-13]. Using nano-HAPs as a vehicle for gene and intracellular drug delivery is dependent on cellular uptake [14]. Moreover, sizes, morphologies, and concentrations of nano-HAPs have a significant influence on responses of normal cells and tumor cells, including cellular uptake, cell proliferation, and cell apoptosis [15-19]. In this study, rod-like nano-HAPs were prepared to investigate behavioral changes of hepatoma cells after cellular uptake of nano-HAPs.

\section{Materials and Methods}

2.1. Preparation and Characterization of Nano-HAPs. Referring to the reported method [20], nano-HAPs were prepared. $\mathrm{Ca}\left(\mathrm{H}_{2} \mathrm{PO}_{4}\right)_{2} \cdot \mathrm{H}_{2} \mathrm{O}$ was dissolved in distilled water and then a solution with a 1.67 ratio of calcium/phosphorus $(\mathrm{Ca} / \mathrm{P})$ was quickly added (molar ratio of $\mathrm{Ca} / \mathrm{P}=1.67$ ) with a saturated $\mathrm{Ca}(\mathrm{OH})_{2}$ solution containing a dispersant. The mixture was stirred vigorously with a magnetic stirring apparatus and sonicated for $30 \mathrm{~min}$ with an ultrasound emulsion-intensifying processing device to prepare the nanoHAPs. The size distribution of nano-HAPs was analyzed by laser particle size analysis, and TEM (Philips CM20, The Netherlands) was used to investigate the morphology of nano-HAPs. The crystalline phase composition of nanoHAPs had been identified using XRD, and so forth, by our group [20-22].

2.2. Cell Culture. Cell studies were performed using the Bel7402 cell line purchased from the China Center for Type Culture Collection, Wuhan University. Cells were cultured in RPMI-1640 medium (Gibco, Grand Island, NY, USA), supplemented with $10 \%$ new-born calf serum (Gibco), and incubated at $37^{\circ} \mathrm{C}$ in a $5 \% \mathrm{CO}_{2}$ incubator (NU-4500E, Nuaire Inc., Plymouth, MN, USA). Nano-HAPs were sterilized in an autoclave at $121^{\circ} \mathrm{C}$ for $20 \mathrm{~min}$ before cell culture.

2.3. Nano-HAPs Incubated with Hepatoma Cells Attached Overnight. Bel-7402 cells in the logarithmic growth phase were resuspended, and $1 \times 10^{4}$ cells $/ \mathrm{mL}$ were seeded into a culture bottle and allowed to attach overnight. The following day, the culture medium was replaced with a medium supplemented with $0.56 \mathrm{mM}$ nano-HAPs and with the same amount of solvent as was used in the control group. Cells were placed in the incubator, and cell growth was observed under an inverted microscope. Cells in both groups were collected in EP tubes after 2, 12, 24, or $48 \mathrm{~h}$ of culture with nano-HAPs and fixed in $2.5 \%$ glutaraldehyde. Thereafter, cell pellets were dehydrated, cleared, embedded, and sectioned. Samples were observed using TEM (H600 TEM/EDX PV9100, Japan).

2.4. Fluorescence Microscopic Observations of Intracellular $\mathrm{Ca}^{2+}$ in Hepatoma Cells. Bel-7402 cells were seeded into $35 \mathrm{~mm}$ diameter culture dishes. The cell treatment procedure was as described above. After cells were treated with nanoHAPs for $24 \mathrm{~h}$, half of the medium in each culture dish was replaced with $5 \mu \mathrm{M}$ fluo-3 working solution $(5 \mathrm{mM}$ fluo-3 stock solution (10 mg fluo-3 dissolved in $17.5 \mu \mathrm{L}$ dimethylsulfoxide) diluted with PBS), and cells were placed in the incubator for another $1 \mathrm{~h}$. These cells were then washed three times with PBS. Fluorescence microscope (BX-60 Olympus, Tokyo, Japan), computer, and high-resolution digital CCD were applied to collect fluorescence images of the fluo-3 calcium fluorescent probe at a wavelength of approximately $490 \mathrm{~nm}$.

2.5. Nano-HAPs Incubated with Suspended Hepatoma Cells. Single-cell suspensions of $5 \times 10^{4}$ cells $/ \mathrm{mL}$ were inoculated into a culture bottle. Nano-HAPs at a final concentration of $2.8 \mathrm{mM}$ were immediately added to the medium, and the same amount of solvent was added to the medium as a control. After incubation, for different times, cells were observed using an inverted microscope. Cells treated for $2 \mathrm{~h}$ were used to prepare TEM specimens to observe nano-HAPs in these cells. Cells treated for $48 \mathrm{~h}$ were evaluated using an inverted microscope for cell survival rate after trypan blue staining.

2.6. Nano-HAPs Incubated with Proliferating Hepatoma Cells. After Bel-7402 cells were seeded and cultured for $48 \mathrm{~h}$, cells that had already proliferated formed large cell clones (cell clusters). Fresh medium containing $0.56 \mathrm{mM}$ of nano-HAPs was renewed every day until cells spread to $>80 \%$ of the bottom of the culture bottle, and the same amount of solvent was renewed in the control group. After confluence was achieved, cells were trypsinized and subcultured. Cells adherent to the culture bottle were observed under an inverted microscope.

Nano-HAPs at a final concentration of $5.6 \mathrm{mM}$ were added to the medium when Bel-7402 cells that had already been proliferated formed large cell clusters. The same medium with the same dose of nano-HAPs, only without cells, acted as a control. The visibility of medium in both groups was observed under an inverted microscope to estimate the continuous cellular uptake of nano-HAPs. After 12 and $24 \mathrm{~h}$, cells in each group were harvested to prepare TEM specimens.

\section{Results}

3.1. Morphology, Average Diameter, and Size Distribution of Nano-HAPs. As presented in Figure 1, the average diameter of HAP particles tested by dynamic laser scattering was $70.8 \mathrm{~nm}$ (range: $44.6-86.8 \mathrm{~nm}$ ). The overall distribution was $16.4-278.8 \mathrm{~nm}$. TEM images indicated that nano-HAPs appeared as tiny rod-shaped particles with a uniform distribution and primarily in a monodispersed status (Figure 2).

\subsection{Effects of Nano-HAPs on Proliferation and Ultrastructure} of Hepatoma Cells. Monodispersed and adherent Bel-7402 cells were incubated with nano-HAPs for $48 \mathrm{~h}$. Cell proliferation slowed compared with that in the control group, although cells remained adhered (Figures 3(a) and 3(b)). According to TEM observations of cells treated for 12, 24, and $48 \mathrm{~h}$, results were as follows: (1) few HAP nanoparticlefilled vesicles were observed within cells, but the number of intracellular vesicles did not significantly increase over 


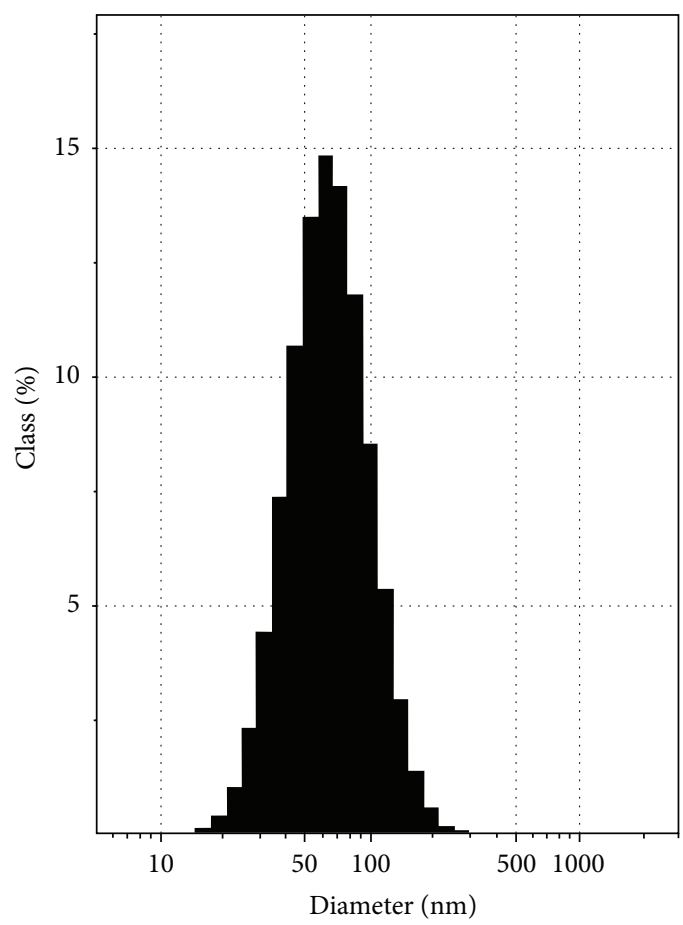

\begin{tabular}{|c|c|c|c|}
\hline Size $(\mathrm{nm})$ & Intensity & Volume & Number \\
\hline 8.4 & 0 & 0.1 & 3.3 \\
9.9 & 0 & 0.3 & 5.2 \\
11.7 & 0 & 0.9 & 8.2 \\
13.9 & 0 & 1.9 & 11.4 \\
16.4 & 0.1 & 3.6 & 13.8 \\
19.3 & 0.4 & 6.2 & 14.6 \\
22.8 & 1.1 & 9.2 & 13.7 \\
27 & 2.3 & 12.1 & 11.2 \\
31.9 & 4.4 & 14 & 8.1 \\
37.7 & 7.4 & 14.1 & 5.2 \\
44.5 & 10.7 & 12.6 & 2.9 \\
52.6 & 13.5 & 9.9 & 1.4 \\
62.2 & 14.8 & 6.8 & 0.6 \\
73.4 & 14.2 & 4.2 & 0.2 \\
86.8 & 11.8 & 2.2 & 0.1 \\
102.5 & 8.5 & 1.1 & 0 \\
121.1 & 5.4 & 0.5 & 0 \\
143.1 & 3 & 0.2 & 0 \\
169.1 & 1.4 & 0.1 & 0 \\
199.7 & 0.6 & 0 & 0 \\
236 & 0.2 & 0 & 0 \\
278.8 & 0.1 & 0 & 0 \\
329.4 & 0 & 0 & 0 \\
389.2 & 0 & 0 & 0 \\
\hline
\end{tabular}

\begin{tabular}{|c|c|c|c|}
\hline \multicolumn{4}{|c|}{ Peak analysis by intensity } \\
\hline Peak & Area & Mean & Width \\
\hline 1 & & & 71.4 \\
\hline \multicolumn{4}{|c|}{ Peak analysis by volume } \\
\hline Peak & Area & Mean & Width \\
\hline 1 & 100 & 39.5 & 41.1 \\
\hline \multicolumn{4}{|c|}{ Peak analysis by number } \\
\hline Peak & Area & Mean & Width \\
\hline & 100 & & 22.3 \\
\hline
\end{tabular}

FIGURE 1: Average diameter and size distribution of nano-HAPs.

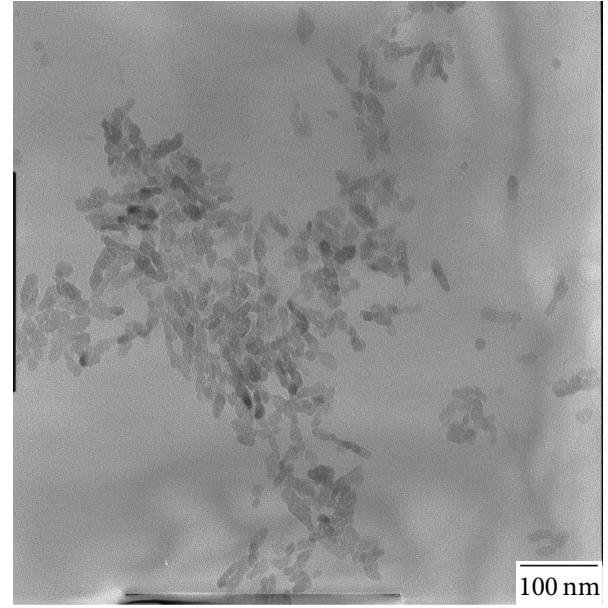

FIgURE 2: The TEM images of nano-HAPs.

time; (2) more vacuoles lay close to the nucleus, and the vesicle membrane was incomplete; (3) vacuole and matrix edema appeared around vesicles in the cells treated for $48 \mathrm{~h}$, mitochondria swelled up, and cristae disintegrated in parts or completely (Figure 4). These findings suggest that nanoHAPs were transported close to the nucleus and may be degraded in the cytoplasm because of the vesicle membrane rupture, resulting in significant changes in cell ultrastructure.

3.3. Influence of Nano-HAPs on Intracellular $\mathrm{Ca}^{2+}$ in Hepatoma Cells. Intracellular free calcium fluorescence intensity was observed under a fluorescence microscope after Bel-7402 cells were labeled with the fluo-3 calcium fluorescent probe for $48 \mathrm{~h}$. The intracellular green fluorescence in the experimental group was enhanced compared with that in the control group, and few cells in the periphery of each cell colony as well as a few cell colonies exhibited strong green fluorescence (Figures 5(a) and 5(b)). Weak fluorescence appeared in the remaining cells of the experimental group, but weaker fluorescence was detected in cells of the control group, and weak fluorescence images could not be collected. Results revealed that nano-HAPs were degraded in Bel-7402 cells, thereby increasing intracellular $\mathrm{Ca}^{2+}$ concentrations.

\subsection{Impact of Nano-HAPs on the Adhesion of Suspended} Hepatoma Cells. Single suspended Bel-7402 cells were incubated with nano-HAPs. After $4 \mathrm{~h}$, suspended cells in the control group had already adhered to the culture bottle, but cells incubated with nano-HAPs had not, and most cells were confirmed dead by trypan blue staining after $48 \mathrm{~h}$. TEM images of the cells incubated with nano-HAPs for $2 \mathrm{~h}$ indicated that vesicles were present and that nano-HAPs were present within vesicles and on surface membranes of cells (Figure 6). These results suggest that continuous cellular uptake of nano-HAPs over $4 \mathrm{~h}$ could cause suspended Bel7402 cells to lose adhesion.

3.5. Nano-HAPs in Cells. Culture medium containing a large dose of nano-HAPs caused the microscopic field of view to become very dark under the inverted microscope when Bel-7402 cells were incubated for $12-24 \mathrm{~h}$. The microscope field increasingly brightened over time; however, no cells were observed as very dark. These findings indicated that 


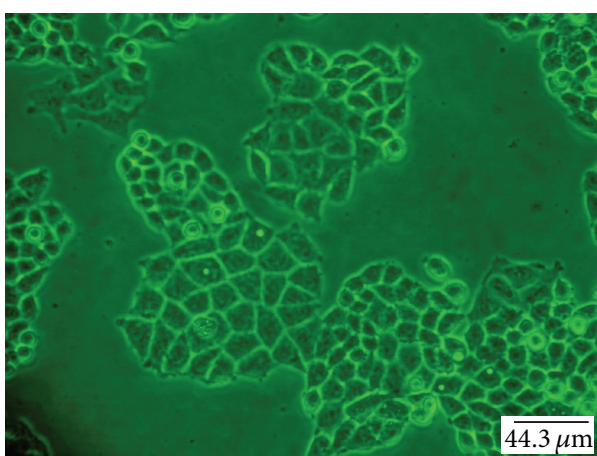

(a) Control group

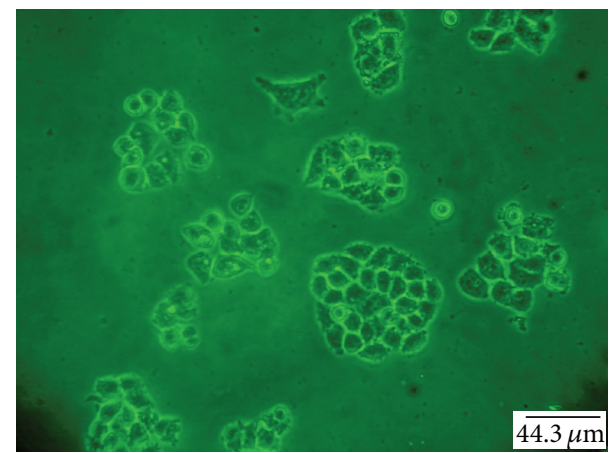

(b) Experiment

FIGURE 3: Inverted microscopic observation of Bel-7402 cells treated with nano-HAPs for $48 \mathrm{~h}$.

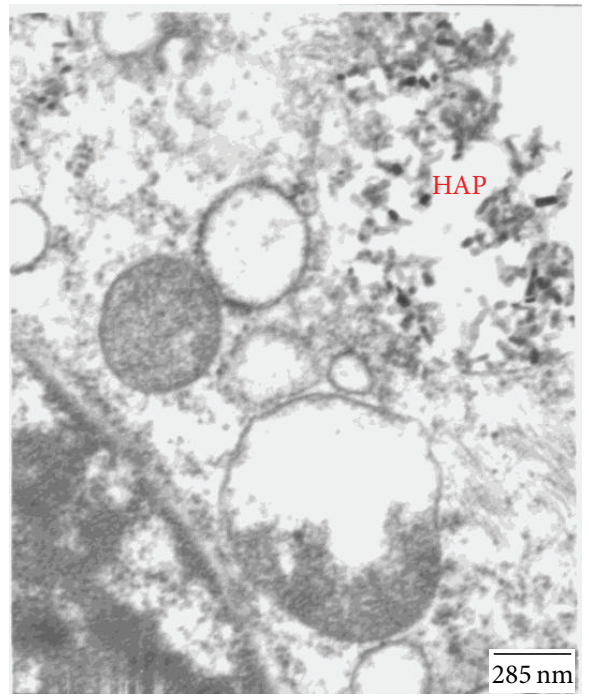

FIGURE 4: TEM images of Bel-7402 cells treated with nano-HAPs for $48 \mathrm{~h}$.

nano-HAPs were taken up continuously by cells. TEM observations of these cells further indicated that a large number of nano-HAPs were present within some vesicles (Figure 7). Therefore, endocytosis of nano-HAPs was very active in Bel7402 cells.

3.6. Effects of Nano-HAPs on Cell Passage. Bel-7402 cells proliferated and formed large cell clusters after a $48 \mathrm{~h}$ culture (Figure 3(a)). These proliferating cells were treated with nano-HAPs every $24 \mathrm{~h}$. Thereafter, proliferation of cells slowed, but these cells reached confluence, despite the fact that they could not attach to the bottom of the culture bottle when they were trypsinized and subcultured. These results suggest that Bel-7402 cells dramatically lost their adhesion ability because of continuous uptake of nano-HAPs.

\section{Discussion}

Vesicular transport carries macromolecules or particulate matter in and out of cells through a membrane package, vesicles formation and membrane fusion, or breakage. The vesicle transport process for cellular uptake of macromolecule or particulate matter in cells is called endocytosis [23]. Cells take up nanoparticles primarily through endocytosis. Few studies have reported that particle size, morphology, and surface charge significantly influence the cellular uptake of nanoparticles. Studies on HeLa cell uptake of nanogold with different diameters $(14,50$, and $70 \mathrm{~nm}$ ) demonstrated that uptake of $50 \mathrm{~nm}$ of nanogold particles was the highest [24, 25]. Motskin et al. [26] recently reported that rod-like nano-HAPs have an appreciable advantage over spherical-shaped nanoparticles with regard to cellular uptake. Although there is repulsion between negatively charged particles and the electronegative cytomembrane, there is evidence that uptake of electronegative nanoparticles by cells can be achieved. For example, Patil et al. [27] reported that negatively charged cerium oxide nanoparticles can be effectively taken up by lung cancer cell lines. In addition, Villanueva et al. [28] reported that HeLa cells take up negatively charged iron oxide nanoparticles but uncharged charged iron oxide nanoparticles are not take up, and negatively charged iron oxide nanoparticles exhibited some toxicity. It is thought that cellular internalization of electronegative nanoparticles can be achieved through endocytosis after nonspecific adsorption of nanoparticles in clusters by the positively charged area of the cell membrane [29]. In this study, we prepared rod-like nano-HAPs with diameters ranging $44.6-86.8 \mathrm{~nm}$ and electronegative hydroxyl groups on the surface. Analysis and observations by inverted microscope and TEM indicated that endocytosis of nano-HAPs into Bel-7402 cells was very active, and occurred continuously. Therefore, nano-HAPs revealed high uptake by these cells. Endocytosis of nano-HAPs is explosive [30]. Kostarelos et al. [31] reported that cellular upkake of carbon nanotubes is very high and that carbon nanotubes in cells can be transported close to the nucleus through cellular obstacles. Nanoparticles that enter cells through endocytosis can be transported to lysosomes for degradation [29]. As other studies have reported, we also found that vesicles with nanoHAPs were transported close to the nucleus after endocytosis. Moreover, concentrations of intracellular $\mathrm{Ca}^{2+}$ labeled by the 


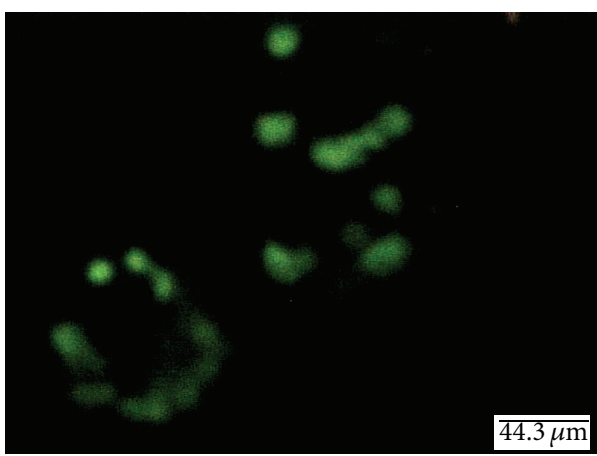

(a) Few cells in the periphery of cell colony

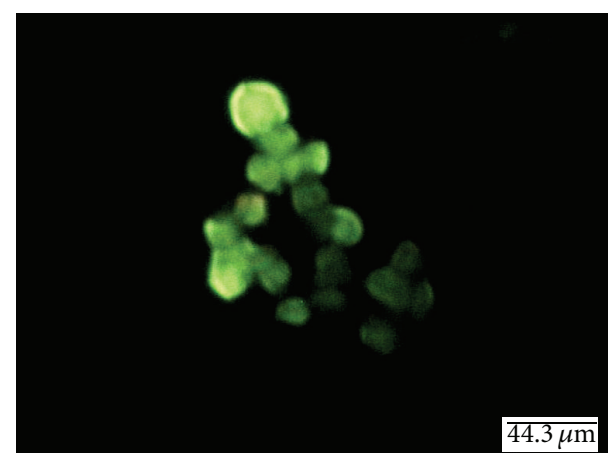

(b) All cell colony

FIGURE 5: Fluorescence microscope observation of intracellular free calcium fluorescence intensity.

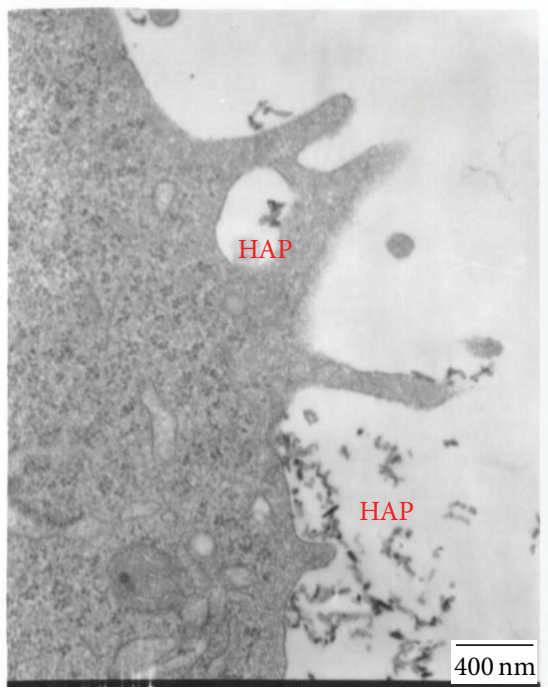

FIGURE 6: TEM images of Bel-7402 cells after the suspension was treated with nano-HAPs for $2 \mathrm{~h}$.

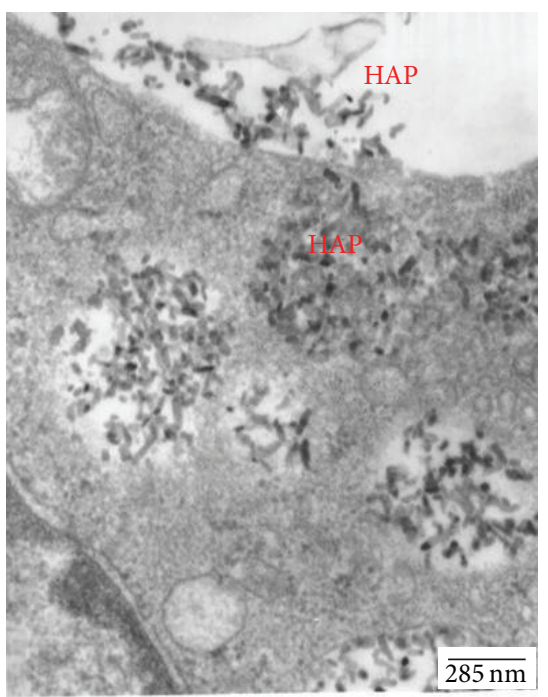

FIGURE 7: TEM images of Bel-7402 cells treated with a large number of nano-HAPs for $24 \mathrm{~h}$.
$\mathrm{Ca}^{2+}$ probe increased. Therefore, nano-HAPs were degraded after cellular uptake, and the degradation product caused changes in Bel-7402 cell ultrastructure, resulting in decreased cell proliferation.

The high and sequential uptake of nano-HAPs through endocytosis resulted in suspended Bel-7402 cells that dramatically lost their adhesion ability and, eventually, died. Although nanoparticles of different sizes, shapes, and material properties are very important for biosystem applications, an understanding of how these cells interact with nanoparticles at the molecular level remains poor. Studies have demonstrated that the size of nanoparticles significantly affects adsorption and activation of membrane receptors and, thus, affects protein expression [25]. Integrin has an adhesion effect, and some cells can proliferate only after adhesion. If the integrin-mediated cell adhesion to the extracellular matrix is hindered, cell apoptosis can occur [32, 33]. Therefore, efficient uptake of nano-HAPs into Bel-02 cells by endocytosis was likely to seriously affect cell membrane integrins, thereby affecting cell adhesion and proliferation, further leading to cell death. Integrins mediate various kinds of cell behaviors such as adhesion, growth, migration, and differentiation, which play an important role in tumorigenesis, tumor metastasis, cell proliferation, cell apoptosis, and signal transduction [34]. Therefore, experimental results suggest that nano-HAPs may have an inhibitory effect on liver cancer metastasis.

\section{Conclusions}

We prepared rod-like, negatively charged nano-HAPs with diameters ranging from 44.6 to $86.8 \mathrm{~nm}$, which revealed high uptake by cells. Nano-HAPs entered hepatoma cells through endocytosis and were transported close to the nucleus and then degraded, resulting in changes in cell ultrastructure and inhibited cell proliferation. More importantly, hepatoma cells uptake of nano-HAPs was very active and occurred continuously. Endocytosis caused suspended hepatoma cells to dramatically lose their ability to adhere, and they eventually died. The very high uptake rate likely affected cell membrane integrin receptors, resulting in hindered integrin-mediated 
cell adhesion. Therefore, nano-HAPs may have an inhibitory effect on liver cancer metastasis.

\section{Conflict of Interests}

The authors declare that there is no conflict of interests regarding the publication of this paper.

\section{Acknowledgments}

This work was supported by the Major Program of National Natural Science Foundation of China (no. 81190133), the National Natural Science Foundation of China (nos. 51172171 and 51002109), the National Natural Science Foundation of Hubei Province (no. 2013CFB354), and the Hubei Polytechnic University (no. 07yjz05R).

\section{References}

[1] L. Chen, J. M. Mccrate, J. C.-M. Lee, and H. Li, "The role of surface charge on the uptake and biocompatibility of hydroxyapatite nanoparticles with osteoblast cells," Nanotechnology, vol. 22, no. 10, Article ID 105708, 2011.

[2] H. Zhou and J. Lee, "Nanoscale hydroxyapatite particles for bone tissue engineering," Acta Biomaterialia, vol. 7, no. 7, pp. 2769-2781, 2011.

[3] K. Sahithi, M. Swetha, M. Prabaharan et al., "Synthesis, characterization, and antimicrobial activity of nano-hydroxyapatitezinc for bone tissue engineering applications," Journal of Biomedical Nanotechnology, vol. 12, no. 1, pp. 167-172, 2012.

[4] Y. Hao, H. Yan, X. Wang et al., "Evaluation of osteoinduction and proliferation on nano-Sr-HAP: a novel orthopedic biomaterial for bone tissue regeneration," Journal of Nanoscience and Nanotechnology, vol. 12, no. 1, pp. 207-212, 2012.

[5] S. H. Chu, D. F. Feng, Y. B. Ma et al., "Hydroxyapatite nanoparticles inhibit the growth of human glioma cells in vitro and in vivo," International Journal of Nanomedicine, no. 7, pp. 3659-3666, 2012.

[6] F. Qing, Z. Wang, Y. Hong et al., "Selective effects of hydroxyapatite nanoparticles on osteosarcoma cells and osteoblasts," Journal of Materials Science: Materials in Medicine, vol. 23, no. 9, pp. 2245-2251, 2012.

[7] W. Tang, Y. Yuan, C. Liu, Y. Wu, X. Lu, and J. Qian, "Differential cytotoxicity and particle action of hydroxyapatite nanoparticles in human cancer cells," Nanomedicine, pp. 1-15, 2013.

[8] J.-W. Wang, C.-Y. Chen, and Y.-M. Kuo, "Preparation and characterization of chitosan-coated hydroxyapatite nanoparticles as a promising non-viral vector for gene delivery," Journal of Applied Polymer Science, vol. 121, no. 6, pp. 3531-3540, 2011.

[9] T. Kimura, Y. Nibe, S. Funamoto et al., "Preparation of a nanoscaled poly(vinyl alcohol)/hydroxyapatite/DNA complex using high hydrostatic pressure technology for in vitro and in vivo gene delivery," Journal of Drug Delivery, vol. 2011, Article ID 962743, 8 pages, 2011.

[10] H. T. Ong, J. S. C. Loo, F. Y. C. Boey, S. J. Russell, J. Ma, and K.-W. Peng, "Exploiting the high-affinity phosphonatehydroxyapatite nanoparticle interaction for delivery of radiation and drugs," Journal of Nanoparticle Research, vol. 10, no. 1, pp. 141-150, 2008.

[11] B. Palazzo, M. Iafisco, M. Laforgia et al., "Biomimetic hydroxyapatite-drug nanocrystals as potential bone substitutes with antitumor drug delivery properties," Advanced Functional Materials, vol. 17, no. 13, pp. 2180-2188, 2007.

[12] D. Olton, J. Li, M. E. Wilson et al., "Nanostructured calcium phosphates (NanoCaPs) for non-viral gene delivery: influence of the synthesis parameters on transfection efficiency," Biomaterials, vol. 28, no. 6, pp. 1267-1279, 2007.

[13] F. Ye, H. Guo, H. Zhang, and X. He, "Polymeric micelletemplated synthesis of hydroxyapatite hollow nanoparticles for a drug delivery system," Acta Biomaterialia, vol. 6, no. 6, pp. 2212-2218, 2010.

[14] L. Hu, Z. Mao, and C. Gao, "Colloidal particles for cellular uptake and delivery," Journal of Materials Chemistry, vol. 19, no. 20, pp. 3108-3115, 2009.

[15] Z. Xu, C. Liu, J. Wei, and J. Sun, "Effects of four types of hydroxyapatite nanoparticles with different nanocrystal morphologies and sizes on apoptosis in rat osteoblasts," Journal of Applied Toxicology, vol. 32, no. 6, pp. 429-435, 2012.

[16] X. Zhao, S. Ng, B. C. Heng et al., "Cytotoxicity of hydroxyapatite nanoparticles is shape and cell dependent," Archives of Toxicology, vol. 87, no. 6, pp. 1037-1052, 2013.

[17] X. Zhao, K. J. Ong, J. D. Ede et al., "Evaluating the toxicity of hydroxyapatite nanoparticles in catfish cells and zebrafish embryos," Small, vol. 9, pp. 1734-1741, 2013.

[18] Y. Yuan, C. Liu, J. Qian, J. Wang, and Y. Zhang, "Size-mediated cytotoxicity and apoptosis of hydroxyapatite nanoparticles in human hepatoma HepG2 cells," Biomaterials, vol. 31, no. 4, pp. 730-740, 2010.

[19] Z. Shi, X. Huang, Y. Cai, R. Tang, and D. Yang, "Size effect of hydroxyapatite nanoparticles on proliferation and apoptosis of osteoblast-like cells," Acta Biomaterialia, vol. 5, no. 1, pp. 338345, 2009.

[20] Y. Han, X. Wang, and S. Li, "A simple route to prepare stable hydroxyapatite nanoparticles suspension," Journal of Nanoparticle Research, vol. 11, no. 5, pp. 1235-1240, 2009.

[21] Y. C. Han, X. Y. Wang, and S. P. Li, "Change of phase composition and morphology of sonochemically synthesised hydroxyapatite nanoparticles with glycosaminoglycans during thermal treatment," Advances in Applied Ceramics, vol. 108, no. 7, pp. 400-405, 2009.

[22] Q.-F. Zhang and Y.-C. Han, "In vitro study on the erythrocyte aggregation caused by hydroxyapatite nanoparticles," Journal of Clinical Rehabilitative Tissue Engineering Research, vol. 12, no. 36, pp. 7143-7146, 2008.

[23] Y. K. Liu and G. M. Chen, "The influence of cell membrane on the transmembrane transport of macromolecule or particulatematter," Modern Medicine and Health, vol. 22, no. 5, pp. 674675, 2006.

[24] B. D. Chithrani, A. A. Ghazani, and W. C. W. Chan, "Determining the size and shape dependence of gold nanoparticle uptake into mammalian cells," Nano Letters, vol. 6, no. 4, pp. 662-668, 2006.

[25] W. Jiang, B. Y. S. Kim, J. T. Rutka, and W. C. W. Chan, "Nanoparticle-mediated cellular response is size-dependent," Nature Nanotechnology, vol. 3, no. 3, pp. 145-150, 2008.

[26] M. Motskin, D. M. Wright, K. Muller et al., "Hydroxyapatite nano and microparticles: Correlation of particle properties with cytotoxicity and biostability," Biomaterials, vol. 30, no. 19, pp. 3307-3317, 2009.

[27] S. Patil, A. Sandberg, E. Heckert, W. Self, and S. Seal, "Protein adsorption and cellular uptake of cerium oxide nanoparticles as a function of zeta potential," Biomaterials, vol. 28, no. 31, pp. 4600-4607, 2007. 
[28] A. Villanueva, M. Canete, A. G. Roca et al., "The influence of surface functionalization on the enhanced internalization of magnetic nanoparticles in cancer cells," Nanotechnology, vol. 20, no. 11, pp. 115103-115112, 2009.

[29] C. J. Liu, W. Wu, Y. Cheng et al., "The transmembrane absorption and transport of macromolecules and nanoparticles," Journal of Southeast University, vol. 30, no. 1, pp. 114-127, 2011.

[30] M.-Z. Yin, X.-Y. Cao, and S.-P. Li, "The pathway of HAP nanoparticle uptake into hepatoma carcinoma cells," Frontiers of Materials Science in China, vol. 4, no. 4, pp. 376-381, 2010.

[31] K. Kostarelos, L. Lacerda, G. Pastorin et al., "Cellular uptake of functionalized carbon nanotubes is independent of functional group and cell type," Nature Nanotechnology, vol. 2, no. 2, pp. 108-113, 2007

[32] M. Kim, C. V. Carman, and T. A. Springer, "Bidirectional transmembrane signaling by cytoplasmic domain separation in integrins," Science, vol. 301, no. 5640, pp. 1720-1725, 2003.

[33] G. J. Mizejewski, "Role of integrins in cancer: survey of expression patterns," Proceedings of the Society for Experimental Biology and Medicine, vol. 222, no. 2, pp. 124-138, 1999.

[34] P. F. Liu, J. Q. Zhang, and Y. C. Feng, "Integrin-betal and tumor metastasis," Modern Oncology, vol. 16, no. 10, pp. 1837-1840, 2008. 

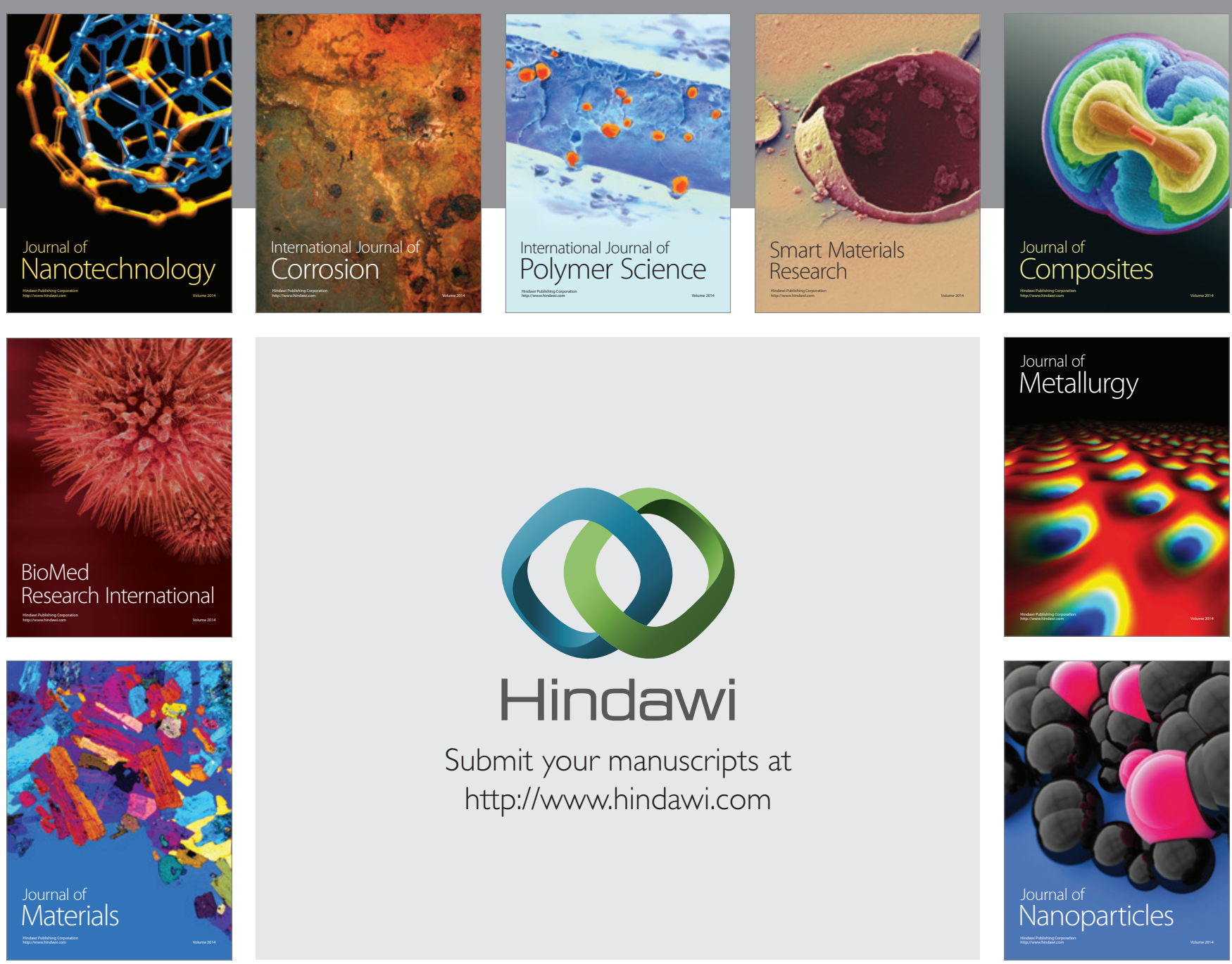

Submit your manuscripts at http://www.hindawi.com
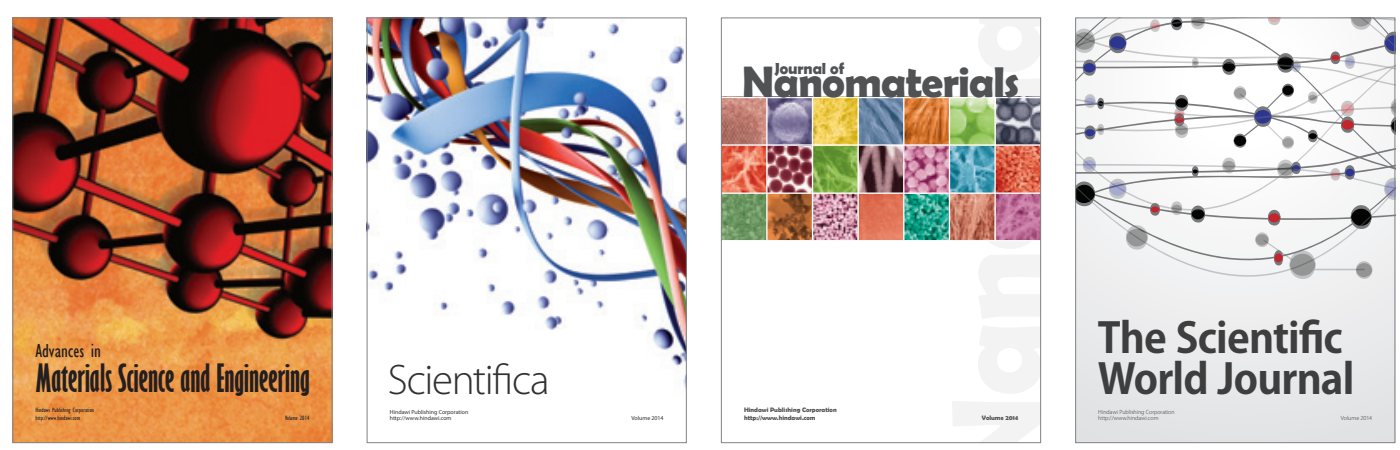

\section{The Scientific World Journal}
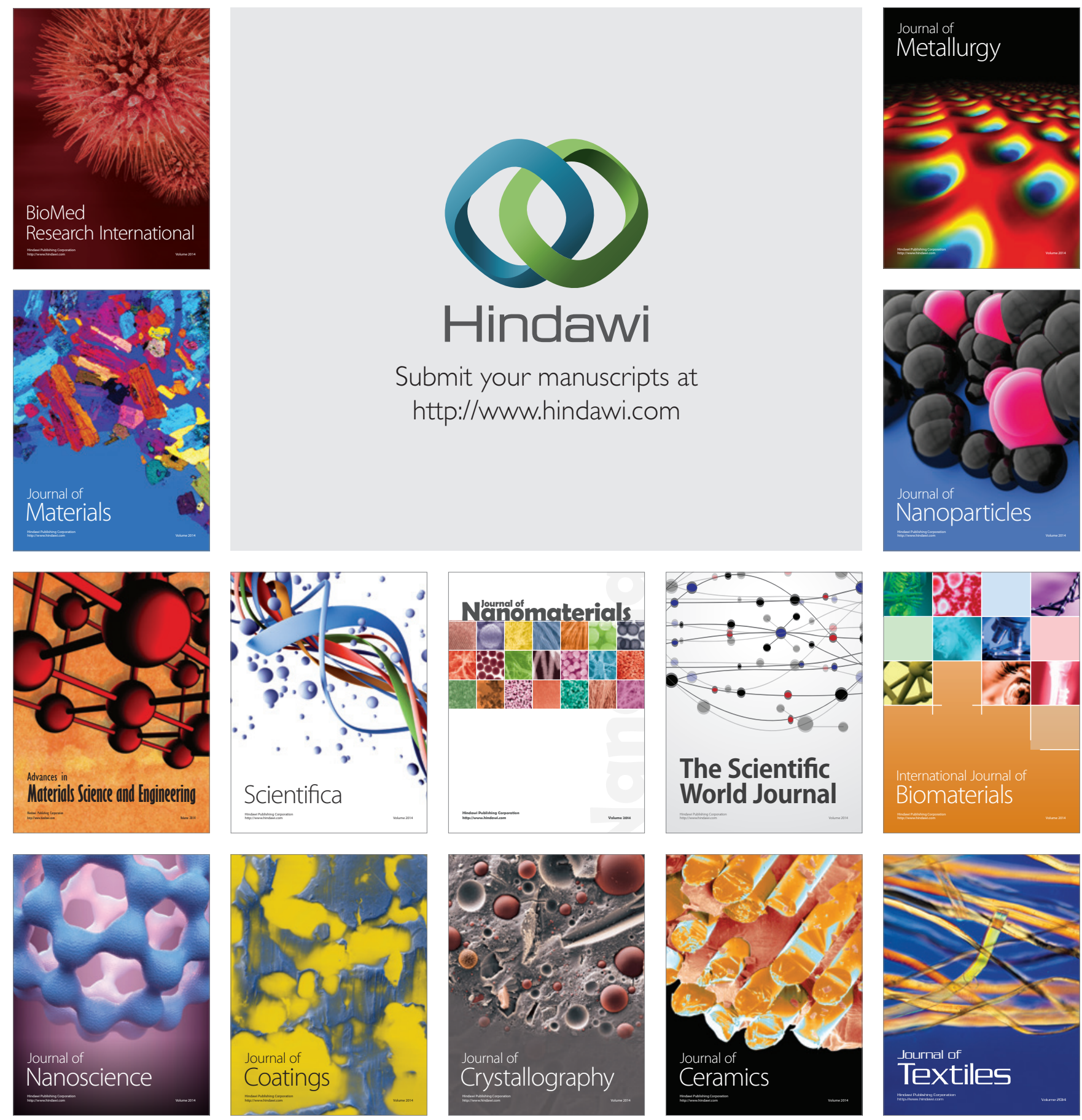